\title{
About the Erosion Hazard Situation of the Slope of the Azerbaijani Lands and its Elimination
}

\author{
Rae ZH Aliyev* \\ Institute of Soil Science and Agrochemistry of the National Academy of Sciences of Azerbaijan, Azerbaijan
}

Submission: October 11, 2018; Published: November 14, 2018

*Corresponding author: Rans ZH Aliyev, Institute of Soil Science and Agrochemistry of the National Academy of Sciences of Azerbaijan, Azerbaijan

Abstract

As a result of the erosion process, considered as a common human problem, the majority of the mountainous and foothills of the Azerbaijan Republic have lost their fertility. Implementation of complex measures to restore lost fertility in these lands is inevitable as demand of the day and has also been reflected in important state programs to be addressed as a specific problem with its relevance. For this purpose, a comprehensive set of measures have been developed and developed in the country, taking into account the ecological conditions of landscapes and climate conditions of natural zones.

Keywords: Soil erosion; Landscape; Bias; Soil cover; Natural and farming

\section{Introduction}

Most of the mountainous and foothold areas of Azerbaijan ( $43.3 \%$ of the country's land) have been exposed to erosion and lost their fertility. In order to restore and maintain the fertility of erosive lands, zonal complex anti-erosion measures should be undertaken. When applying combat measures, soil-vegetation cover of natural zones, climatic conditions, degree of soil erosion, slope tendencies and ecological conditions of landscapes should be taken into account (Figure 1).

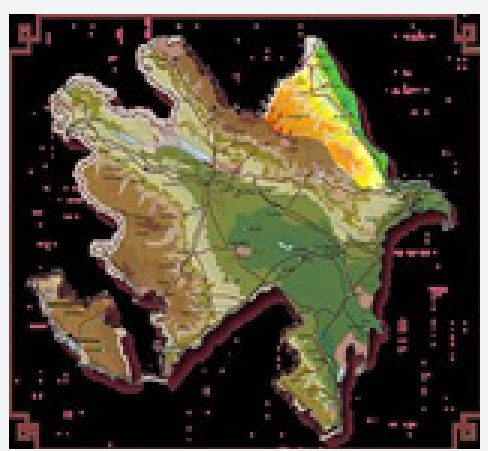

Figure 1: Most of the mountainous and foothold areas of Azerbaijan.

Soil-vegetation cover, bio-gum and so on, in the territory of the Republic, including the Minor and the Greater Caucasus, rise from the sea level to the altitude. Accordingly, different natural areas are separated. Hydrotechnical, agrotechnical, phytomelorative (forest and grass melorma) measures should be implemented in complex and complementary conditions to protect soil cover from erosion.
In addressing the problem of land erosion, it is necessary to overcome the factors leading to its occurrence.

First of all, economic and organizational measures should be taken. It is of utmost importance to use erosionous and erosive lands more efficiently, to restore soil fertility, to ensure the proper location of farms, perennial plantings, forest strips and roads taking into account the relief structure and soil conditions.

Large-scale land surveys should be undertaken in order to design erosion measures, to properly organize the area and placement of agricultural crops on a scientific basis. A map of erosion factors and a map of anti-erosion measures should be drawn up for the study areas.

The Scientific Research Institute of Erosion and Irrigation developed maps for a number of farms in mountainous and foothills regions of the Republic. Land protection schemes should be applied on slopes up to 5o and in areas with poor and washed out areas where cultivated crops should be cultivated primarily. $20 \%$ of this turnover should be perennial herbaceous plants. The results of research conducted at the Erosion and Irrigation Institute over the past 30 years have shown that the 5-10 slopes should dominate the grazing crops in the rotating sowing system and should not exceed $20-25 \%$ of the cultivated crops. Plants in perennial shrub transplants should have $25-30 \%$ perennial herbs.

Seedlings planted at the slopes of $10-15^{\circ}$ should be fully cropped up and crop rotation of perennial herbs should be 
up to $60 \%$ in the sowing system. In cultivated areas where severe erosion is required, cereal crops should be completely discontinued. In such areas, only perennial herbs should be planted. This event protects the soil from erosion well and is very economically beneficial. It is better to stop cultivation of field crops in areas with temperatures above $15^{\circ}$ and use them as natural fodder.

Anti-erosion control measures on the slopes (plowing and other cultivation works along the slope width, flooding of water and buffer strips, deep lubrication, etc.) improves the water-physical properties of the soil, prevents the surface flow and creates moisture in the soil. Thus, in the slopes with 8-10응 slopes, the amount of soil that washed in the slopes is reduced by 2.5 times, humidity is $3-4 \%$ and fertility is $21.2 \%$.

It should be noted that on the sloping slopes, it is only possible to prevent the erosion process completely when it is pushed along the slope width. Additional anti-erosion measures should be undertaken on such slopes. One of these measures is the opening of the puddles that keep water in the direction of the slope when ice creeping. Rainfall prevents surface water flow and drainage, increases moisture content in soil, increases productivity of agricultural crops.

It has been established that deep softening of soil with strips in the prevention of erosion is of great economic significance. This measure prevents the surface flow of $75-80 \%$, the sediment is well ground to the soil, and so the water-physical property of the soil improves considerably. Opening of cracks in the slopes is of great importance in soil-saving agrotechnical measures. Roughing, plowing, pasturing, and mowing, and so on. Gives excellent results in areas.

Cuttings on perennial herbaceous crops should be carried out in the autumn when the soil is condensed, and in autumn sowing areas before sowing or soil. The bedrock reduces the water flow of the soil, prevents its washing, increases the amount of moisture in the soil, and thus significantly reduces the productivity of agricultural crops as it is well known, the erosion process in the summer and winter pasture areas is widespread.

Thus, more than $80 \%$ of summer pastures, and $60 \%$ of winter pastures have been exposed to erosion. Therefore, it is necessary to keep cattle grazing and livestock breeding in order to meet the high nutritional requirements of livestock and to obtain highquality feeds.

Proper compliance with grooming time and norms will result in surface and basic improvements $90 \%$ of forests in the Republic are located in the mountainous areas. Their water-soluble and soil-protecting role is indispensable. Forests do not allow the flow of water and regulate the water regime. In addition, forests have a great resort value. However, as a result of forest breakage or cattle grazing, forest lands are eroded. For this reason, about $20 \%$ of the forests have been eroded in our study area. More than $80 \%$ of the underground forest was exposed to erosion.
Therefore, protection of forests should be given special attention, conditions should be created for good restoration, and measures should be taken to create new forests in open and dry areas. The erosion of the country is also widespread. Cultivation erosion as a result of planting, knitting and so on.

The spheres are broken down and become useless. So it is important to take measures to combat the ravine erosion. There are many extinctions in the mountainous and foothill regions of the Republic, that is, the developmental slopes. On the slopes of these hills, it is possible to create fields to sow the seeds of perennial herbs, which also tighten the walls of the cup.

When mounting the gobs, special attention should be paid to the development of forests in and around it. It is necessary to plant trees and bushes to fasten areas of rocks. In order to avoid sliding on slopes, it is necessary to direct the surface water flow to another location. To do this, drainage on the slopes should be used. Hydrotechnical constructions should be used to protect river basins from erosion, floods in the Republic.

These constructions help prevent the flood by sinking the coastal material that has been created as a result of the erosion process, protecting the coast of the river from collapsing. Along with water erosion, wind erosion is widespread throughout the territory of the Republic. The air conditioning process is one of the main factors causing erosion and occurs in the foothills of the Lesser Caucasus. Complex measures must be taken to prevent soil and sand from being drawn by winds.

When planting forest strips, the dominant wind direction, strength and so on. Should be taken into account. The abovementioned measures should be implemented in a coherent manner in order to protect the soil cover and to increase the efficiency of its use. If every farm fights correctly, the land is protected from rupture, its fertility increases, resulting in a higher and stable harvest of agricultural crops.

More than $20 \%$ of the territory of the Republic over the past 15 years has been occupied because of Armenia's aggression and has long turned into a bloody battleground. Here, military erosion has developed extensively. Toxic bombs, bullets and mortar missiles have destroyed hundreds of villages, towns, and several districts, ruining landscapes, demolishing the land, cutting off a thousand hectares and sowing their vineyards. It has poisoned and polluted the toxicological environment by using toxic substances during the war. Such lands should be thoroughly cleaned with systematic and ameliorative measures after their occupation and the land should be treated with special care. Here, complex measures must be taken to return the lands to agricultural turnover. The soil should be subjected to toxicology.

Zone genocide has also occurred in the area that has turned into a battlefield. Thus, in the war-ravaged areas, all creatures have fled, and there is no chance to find sparrows here. All this has created ecosystems that have disrupted ecosystems, disrupted the ecosystems and caused a great impact on the 
ecological situation. Complex, melorative and special measures are also required in areas to be liberated [1-9].

\section{Conclusion}

In progress soil erosion in mountain and foothills of the Republic, large parts loss fertility. For resto ration here. To this end, it is necessary to have at least one aspect of the climate, covering vegetation, and even naturally environmental aspect decision.

\section{References}

1. Aliyev BH, Aliyev İN, Aliyev ZH (2000) Problems of erosion in Azerbaijan and its solution. Search for: ZIL INPTS Nurlan. Baku-2000 p.122.

2. Aliev BH, Aliev ZH (2001) Zoning of territory of Azerbaijan Republic on choosing advanced irrigation techniques. Monograph, Publishing house "Ziya" Baku, p. 297

3. Aliev BH, Aliev ZH (2003) Irrigated agriculture in the mountain and foothill regions of Azerbaijan. Monograph Publishing house "Nurlan Zia EPG Ltd" Baku, p. 330
4. Aliev ZH (2007) The premises about the most important problem of the agriculture in provision water resource mountain and foothill regions Azerbaijan. J. AAS Baku, p.179-182.

5. Aliev ZH (1999) The premises of the decision of the problems moisture provides agriculture cultures production in mountain and foothill region Azerbaijan. The works SRI "Erosions and Irrigations, Baku, p.125-129.

6. Aslanov ГК (1999) Melioration on the gray territories of Azerbaijan Baku Science.

7. Mammadov Gsh (1987) Methodological indications on the semiotic cultivation of cereals. P. 197.

8. Mammadov Q, Khalilov M (2004) Ecology and the environment. Baku Science, p. 505.

9. Şakuri BS (2008) Influence of mineral and microorganisms on biological processes in gray-brown mountain-brown and carbonate mountain-gray-brown (chestnut) soils of the Greater Caucasus. Land and water resources protection. Baku, №3.

Your next submission with Juniper Publishers will reach you the below assets

- Quality Editorial service

- Swift Peer Review

- Reprints availability

- E-prints Service

- Manuscript Podcast for convenient understanding

- Global attainment for your research

- Manuscript accessibility in different formats

(Pdf, E-pub, Full Text, Audio)

- Unceasing customer service

Track the below URL for one-step submission https://juniperpublishers.com/online-submission.php 